\title{
TECHNICAL EVOLUTION AND RELIABILITY OF TROLLEYBUS'S TRACTION TRANSMISSION
}

Based on the analysis of the indicators of functionality and structure of the trolleybus's traction transmission (TT), some characteristic differences have been established for the classification of 4 generations of drive axles $(D A)$ structures of known world manufacturers. The calculation models and methods for increasing the probability of a fail-safe transmission's and $D A$ system work, consisting of aggregates, modules, mechanisms, parts and connections, are analyzed. A method is proposed and example is given of predicting the parametric reliability of a planetary wheel gear $(P W G)$ in $D A$ system by two criteria: fatigue strength and vibration resistance of "criteria element" - thin-walled epicycle of "weak link" - $P W G$.

Keywords: transmission's classification, models of reliability, drive axles, planetary wheel gear, ring, fatigue strength, vibration resistance.

\section{Г. О. ОБОРСЬКИЙ, С. С. ГУТИРЯ, В. П. ЯГЛІНСЬКИЙ, А. М. ЧАНЧІН}

\section{ТЕХНІЧНА ЕВОЛЮЦІЯ ТА НАДІЙНІСТЬ ТЯГОВОЇ ТРАНСМІСІЇ ТРОЛЕЙБУСА}

На підставі аналізу показників функціональності і структури тягової трансмісії (TT) тролейбусів встановлено характерні відмінності для класифікації 4-х поколінь конструкцій тягових мостів (TM) відомих світових виробників. Проаналізовано розрахункові моделі та методи підвищення ймовірності безвідмовної роботи систем TT і TM, що складаються з агрегатів, модулів, механізмів, деталей, з'єднань. Запропоновано методику та наведено приклад прогнозування параметричної надійності планетарного колісного редуктора (ПКР) за двома критеріями: втомної міцності та вібростійкості "критеріального елементу" - тонкостінного епіциклу у складі "слабкої ланки" - ПКР.

Ключові слова: класифікація трансмісій, моделі надійності, тяговий міст, планетарний колісний редуктор, епіцикл, утомна міцність, вібраційна стійкість.

\section{Г. А. ОБОРСКИЙ, С. С. ГУТЫРЯ, В. П. ЯГЛИНСКИЙ, А. Н. ЧАНЧИН \\ ТЕХНИЧЕСКАЯ ЭВОЛЮЦИЯ И НАДЕЖНОСТЬ ТЯГОВОЙ ТРАНСМИССИИ ТРОЛЛЕЙБУСА}

На основании анализа показателей функциональности и структуры тяговой трансмиссии (TT) троллейбусов установлены характерные отличия для классификации 4-х поколений конструкций тяговых мостов (TM) известных мировых производителей. Проанализированы модели расчета и методы повышения вероятности безотказной работы систем $T T$ и $T M$, состоящих из агрегатов, модулей, механизмов, деталей, соединений. Предложена методика и приведен пример прогнозирования параметрической надежности планетарного колесного редуктора $($ ПКР) по двум критериям: усталостной прочности и вибростойкости "критериального элемента" - тонкостенного эпицикла в составе "слабого звена" - ПКР.

Ключевые слова: классификация трансмиссий, модели надежности, тяговый мост, планетарный колесный редуктор, эпицикл, усталостная прочность, вибрационная устойчивость.

1. Customer requirements and functional properties of traction transmissions. Customers, designers and operating companies are extremely interested in objective information about the characteristics and quality of the serial models of trolley and electric buses available in the world market, because of their high cost, significant periods of use and depreciation, and intensive operating conditions. This information, in addition to economic indicators, should contain indicators of technical excellence of the vehicle for a reasonable choice of a certain model when ordering, scheduling maintenance intervals, and determining effective directions to extend the periods of reliable operation. As is known because of the intense competition between manufacturing firms, much of this information, in particular regarding operational reliability, is a technical and commercial secret. The purpose of this study is to form a nomenclature of physically informative indicators of the technical perfection of trolleybuses and an information base for determining the trends of models of known world manufacturers, research of the directions of the technical evolution of trolley's traction transmissions (TT) and their system reliability indicators, to justification further researches.

Certain trends in the technical evolution of trolleybuses and electric buses determine the corresponding requirements of consumers for the structure of $T T$, its design, characteristics and parameters systematically associated with the relevant indicators of energy efficiency, ergonomics and operational reliability $[1,2]$.
By the method of energy transformation and power transmission, most of traction transmissions in modern trolleybuses are electromechanical, consisting of traction electrical motor (TEM), as well as lever, friction and gear mechanisms. Characterized by the following advantages in comparison with mechanical or hydro-mechanical transmissions:

- Free choice of wheel formula and simplicity of circuit layout for various types of electric transport, in particular for trolleybuses with lowered floor level.

- High traction and dynamic characteristics providing for multi-body trolleybuses uses with increased passenger capacity.

- Smooth adjustment of track force, relative simplicity of automation of control systems and active safety of vehicle.

- High energy efficiency due to minimal energy losses in the process of transformation, transmission to the driving wheels and electro-dynamic energy recovery during braking.

- Greater reliability and regulatory durability due to less complex design (no clutch and gearbox).

- Lower costs for manufacturing, operation and maintenance.

At the same time, the electromechanical transmission has a disadvantage in comparison with the electrical one - a larger mass of the constituent units, modules and mechanisms, which requires additional measures for vibration isolation.

(C) G. O. Oborskyi, S. S. Hutyria, V. P. Yaglinskyi, A. N. Chanchin, 2018 
The main sources of mechanical vibrations in trolleybuses are rotary parts and movable joints of transmission. The totality of mechanical oscillations of the electromechanical TT forms a structural noise which, under resonant regimes or with significant disturbing forces, can lead to damages the "weak links" not only during the warranty period, but also during the normal inter repair cycle. The structural component of noise is caused by forced oscillations under the influence of perturbing engine forces, gears, technical condition of the road surface, suspension etc.

The following types of oscillatory processes are distinguished in the simulation of $T T$ vibration activity:

- Transient (when the trolleybus is moved from its place and during electrodynamics braking under the influence of linear overloads);

- Low-frequency stationary in the range up to $20 \mathrm{~Hz}$ (when driving on a rise with a slope of $4 \ldots 8 \%$ at maximum traction effort);

- Mid-frequency and high-frequency stationary, due to the process of multi-pair engagement of the row and planetary gear teeth and the movements of the "floating suspension" of the central wheel couplings $P W G$ in the presence of manufacture and installation errors.

The specified set of requirements for the $T T$, the need to adapt to low floor models of passenger transport, certain trends in specific indicators of TEM power, mass of trolleybus and ergonomics [1,2] led to a number of evolutionary changes in the structure and design of drive axles (DA), namely:

- Module of $D A$, used in trolleybus from about 1958 model year (hereinafter $D A$ the $1^{\text {st }}$ generation), has a structure borrowed from buses and trucks (the beam, two semi-axles, main gearing, mechanical center differential, two planetary wheel gears $-P W G$ ) (fig. 1, $a$ ).

- Since 1995, DA received a lower beam, in-line bevel gear ( $I B G$ instead of $P W G$ ) and the corresponding name - portal $D A$ (hereinafter $D A$ the $2^{\text {nd }}$ generation). Purpose - for transmissions with a group drive of the driving trolley's wheels from the TEM through the cardan's mechanism, conical transmission with a circular tooth, the inter axle conical differential, the semi-axes connected with the $I B G$ (transmission cylindrical helical gear with branching, the slow gear is directly connected to the driving wheel, fig. $1, b$ ).

- In 2005 the use of portal $D A$ based on motorwheels with aggregated asynchronous TEM, IBG and $P W G$ (without cardan's mechanisms, semi-axles, final drive and mechanical axis differential (hereinafter $D A$ the $3^{\text {rd }}$ generation). Purpose - for electromechanical transmissions with individual drive of each traction wheel (aggregated motor-wheels $-A M-W$ ), in which TEM are connected with a two-stage $I B G$ and a single-stage $P W G$ (transmissions of cylindrical, helical, fixed ring are located in the hubs of the $A M-W$ the carrier is connected with a driving wheel, fig. 2).

- In 2014 the production of portal $D A$ based on integrated motor-wheels $(I M-W)$ with synchronous TEM on permanent magnets with water cooling and disk brake with hydraulic drive (without cardan's mechanisms, semiaxes and gears (hereinafter $D A$ the $4^{\text {th }}$ generation, fig. 3 ).
The purpose is for electric transmissions with an individual drive, in particular an electric bus for transporting passengers inside airports, the beam of $D A$ the $4^{\text {th }}$ generation includes a beam with two $I M-W$ located on it.

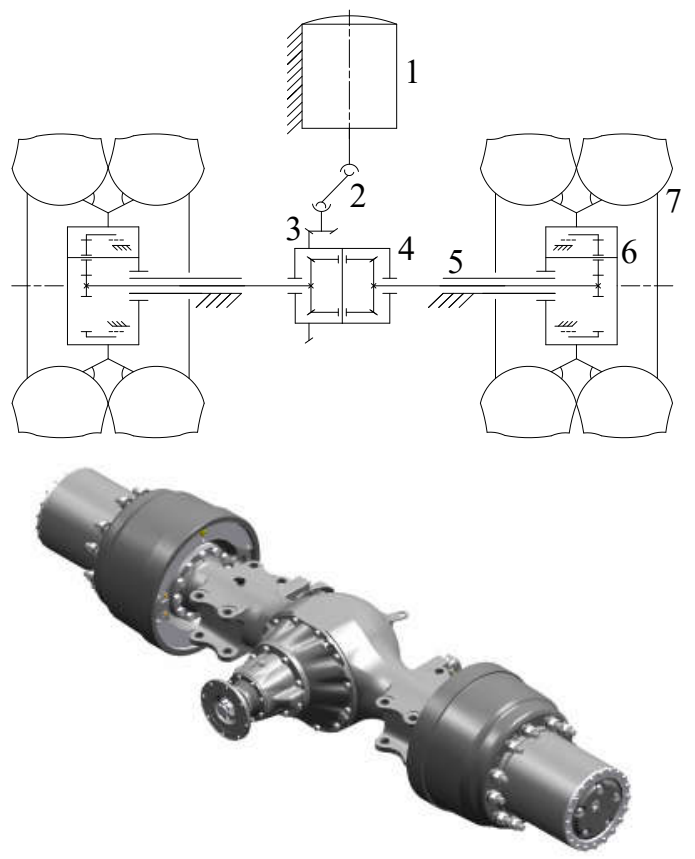

$a$
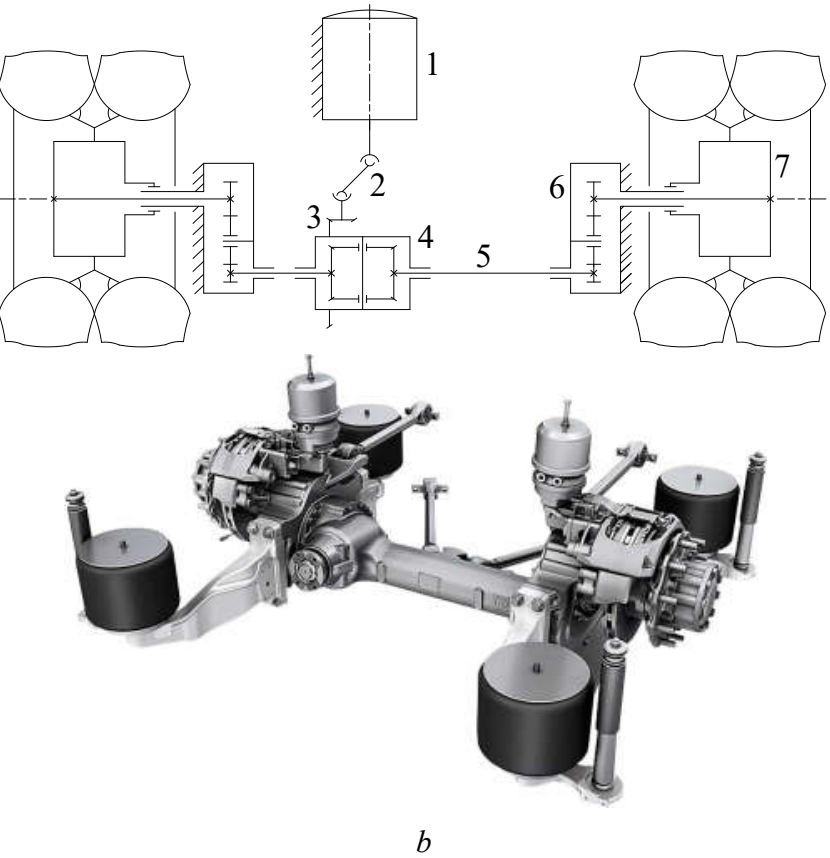

Fig. 1 - Transmission scheme and the $3 D$ model of $D A$, produced by the firm Raba, Hungary, and the firm $Z F$, Germany:

$$
\begin{gathered}
a-\text { the } 1^{\text {st }} \text { generations; } b-\text { the } 2^{\text {nd }} \text { generations; } \\
1-T E M ; 2-\text { cardan's mechanism; } \\
3 \text { - main gear; } 4-\text { mechanical differential; } \\
5-I B G ; 6-P W G ; 7 \text { - driving wheel }
\end{gathered}
$$

2. Classification and analysis of the $T T$ structures. The named $T T$ is convenient to distinguish according to a number of classification features (table 1). 


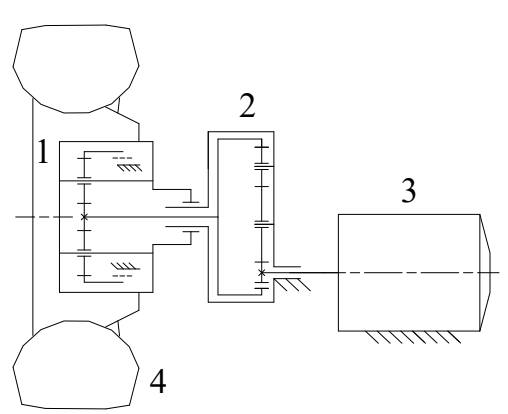

$a$

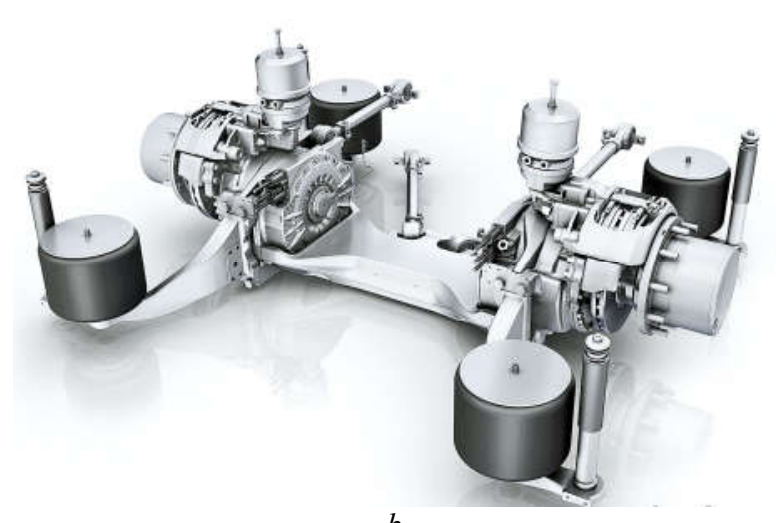

$b$

Fig. 2 - The $3^{\text {rd }}$ generation type $A V E-130$, produced by the firm $Z F$, Germany: $a$ - scheme of the $A M-W ; b$ - the $3 D$ model of $D A ; 1-P W G ; 2-I B G ; 3$ - asynchronous $T E M ; 4$ - driving wheel

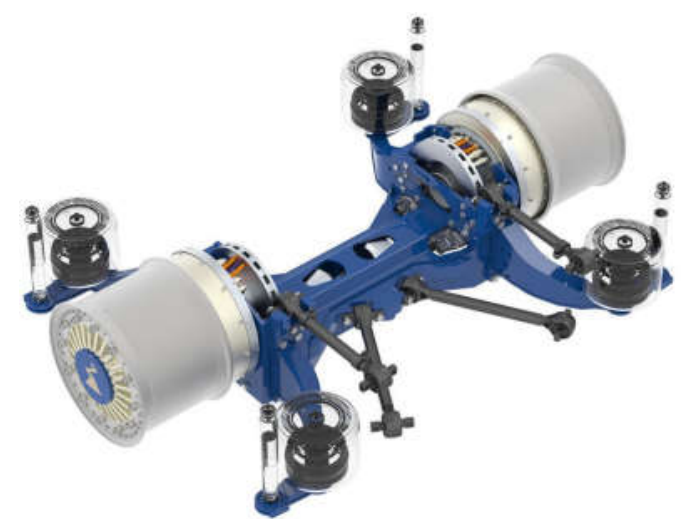

Fig. 3 - The $3 D$ model of $D A$ the $4^{\text {th }}$ generation with $I M$ - $W$ type ZAwheel SM 530, produced by the firm ZIEHL-ABEGG, Germany

Table 1 - Classification features of $T T$

\begin{tabular}{|c|c|c|c|c|}
\hline \multirow{2}{*}{$\begin{array}{l}\text { Features, } \\
\text { examples }\end{array}$} & \multicolumn{4}{|c|}{ Trolleybus's and electric bus floor level } \\
\hline & not lowered $(>480 \mathrm{~mm})$ & \multicolumn{3}{|c|}{ lowered $(320 \ldots 350 \mathrm{~mm})$} \\
\hline 1. The motion energy & \multicolumn{3}{|c|}{ electromechanical } & electrical \\
\hline $\begin{array}{l}\text { 2. Drive scheme } \\
\text { (wheel formula) }\end{array}$ & group $(4 \times 2 ; 6 \times 4)$ & group $(4 \times 2 ; 6 \times 4)$ & $\begin{array}{l}\text { individual } \\
(4 \times 2 ; 6 \times 4)\end{array}$ & $\begin{array}{c}\text { individual } \\
(4 \times 2 ; 4 \times 4 ; 6 \times 4)\end{array}$ \\
\hline $\begin{array}{l}\text { 3. Constituents of transmissions: } \\
\text { engines, modules, units, mecha- } \\
\text { nisms }\end{array}$ & $\begin{array}{l}\text { TEM, cardan's mecha- } \\
\text { nisms, } \\
\text { module of } D A \\
\text { with not lowered beam }\end{array}$ & $\begin{array}{l}\text { TEM, cardan's mecha- } \\
\text { nisms, } \\
\text { module of } D A \\
\text { with not lowered beam }\end{array}$ & $\begin{array}{c}\text { traction } \\
\text { aggregate motor-wheels } \\
(A M-W), \\
\text { module of } D A \\
\text { with lower beam }\end{array}$ & $\begin{array}{l}\text { traction integrated } \\
\text { motor-wheels } \\
(I M-W), \\
\text { module of } D A \\
\text { with lower beam }\end{array}$ \\
\hline 4. Type and construction of TEM & $\begin{array}{l}\text { permanent } \\
\text { current }\end{array}$ & $\begin{array}{c}\text { permanent or } \\
\text { alternating current }\end{array}$ & \begin{tabular}{c|} 
asynchronous \\
3-phase, \\
aggregated \\
with gears \\
\end{tabular} & $\begin{array}{c}\text { synchronous on per- } \\
\text { manent magnets, inte- } \\
\text { grated } \\
\text { in the drive wheel }\end{array}$ \\
\hline $\begin{array}{l}\text { 5. Presence and location of the } \\
\text { main gear and differential }\end{array}$ & central & offset & - & 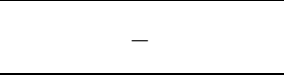 \\
\hline $\begin{array}{l}\text { 6. Presence and types } \\
\text { of split gears }\end{array}$ & $\begin{array}{c}\text { planetary } \\
\text { wheel gears }(P W G)\end{array}$ & $\begin{array}{c}P W G \text { or single-stage } \\
\text { in-line bevel gear }(I B G)\end{array}$ & $\begin{array}{c}P W G \text { and } \\
\text { two-stage } I B G\end{array}$ & - \\
\hline $\begin{array}{l}\text { 7. Type of differential } \\
\text { kinematic connection }\end{array}$ & $\begin{array}{l}\text { mechanical and } \\
\text { electromechanical } \\
\text { (with two } D A \text { ) }\end{array}$ & $\begin{array}{l}\text { mechanical and } \\
\text { electromechanical } \\
\text { (with two } D A \text { ) }\end{array}$ & electric & electric \\
\hline $\begin{array}{l}\text { 8. Examples of schemes and } \\
\text { constructions }\end{array}$ & Fig. 1, a & Fig. 1, b & Fig. 2 & Fig. 3 \\
\hline $\begin{array}{l}\text { 9. Examples of use in produced } \\
\text { models }\end{array}$ & $\begin{array}{c}\text { ZiU-682 GM, Skoda 14Tr, } \\
\text { UMZ-T1, DAC-217E, } \\
\text { BKM-32100D, } \\
\text { Ikarus } 415.80 T, E 40 L F R\end{array}$ & $\begin{array}{c}\text { Neoplan Electroliner 6216, } \\
\text { ExquiCity 18, } \\
\text { ZK6125BEVG5, } \\
\text { Bogdan T701.15, } \\
\text { Hess SwissTrolley } 4\end{array}$ & $\begin{array}{c}\text { XT60, "New Flayer In- } \\
\text { dustries" }\end{array}$ & $\begin{array}{l}\text { Volvo } 7700, \\
\text { Citea SLF-120 } \\
\quad \text { Electric }\end{array}$ \\
\hline
\end{tabular}

So the electromechanical TT of modern trolleybuses with a group or individual drive scheme can consist of a TEM of direct or alternating current, cardan's mecha- nisms, as well as one or two $D A$ with no lowered or lowered (portal) beam. In transmissions with a group drive scheme, the $D A$ module can consist of a main transmis- 
sion of a conical or hypoid, a conical differential, semiaxes of the same or different lengths and split gears.

For $D A$ the $1^{\text {st }}$ generation with a non-lowered beam, the central location of the main gear and the inter-axle mechanical differential with the axle shafts having the same length, which ensures the symmetry of the dynamic load of the transmission along the sides of the trolleybus, are characteristic. All this is placed in the hull, forms a beam of $D A$ (fig. 1, a). The use of compact multi-threaded gears $(M T G)$ makes it possible to reduce the dimensions and mass of the main gear and semi-axles by $1,5 \ldots 2$ times. The $D A$ half-axes can have different lengths, which makes it possible to take out the cardan's shaft away from the middle of the passenger compartment, place the TEM on the rear cantilever part of the trolleybus body as close as possible to the $D A$, allows for partial lowering of the floor in the cabin, simultaneously simplifies the transmission design and improves its reliability (fig. 1, $b$ ).

In schemes with electrical differential coupling, the torque from the TEM built into the motor-wheel is transmitted to the corresponding drive wheel through the $I B G$ and the $P W G$ (fig. 2, $a, b$ ). The coordination (differential kinematic connection) between the pair of drive wheels on each axis of the trolleybus provides an electronic control system. If there are two $D A$ in the transmission, the differential connection between the moving wheels is electromechanical, that is, between the wheels of each $D A$ the speed matching provides a mechanical differential, and between the TEM of the various bridges is the electronic synchronization unit.

Modules of $D A$ the $1^{\text {st }}, 2^{\text {nd }}$ and $3^{\text {rd }}$ generations contain gears with a total gear ratio $u=5,11 \ldots 10,67$, which is realized by the central hypoid $(u=3,09)$ or conic $(u=2,72)$ transmissions and $P W G$ or $I B G(u=3,33 \ldots 3,46)$. Due to the insufficient balance between torque, mass and volume of $T E M$ for each $A M-W$ in $T B$ of the $3^{\text {rd }}$ generation, two gear boxes ( $I B G$ and $P W G$ ) provide a transmission ratio of the transmission at the level of $20 \ldots 23$ and the necessary compactness of the whole structure.

Transmissions based on $D A$ of the $4^{\text {th }}$ generation with the $I M-W$ (fig. 3) do not require cardan's mechanisms, semi-axles and multistage gears, provides the following advantages compared to the $D A$ of the $3^{\text {rd }}$ generation: increased energy efficiency due to a larger $5 \ldots 7 \%$ of the value of the efficiency $\eta=0,9 \ldots 0,92$, the possibility of energy recovery for charging the batteries during electrodynamic braking; greater vibration resistance and a lower mass of the $D A$ in general. The $I M-W$ design can be used in two options - like a rotary or non-rotating motor-wheel, the corresponding wheels can be single-track (equipped with wide tires) or dual-track. For the well-known serial models of $D A$ the $4^{\text {th }}$ generation, the nominal noise level is set at $65 \mathrm{dBA}$. To date, only the high known cost (10 thousand euro) and lack of data on the regulatory resource of $D A$ the $4^{\text {th }}$ generation limit their widespread use in electric wheel passenger transport.

Results of the analysis of the $T T$ structures (see table 1) confirm steady demand for the $P W G$, which are applied as in $D A$ the $1^{\text {st }}$ generation (trolleybuses since the $1955^{\text {th }}$ model year) and also in the modern $D A$ the $3^{\text {rd }}$ generation (since the $2005^{\text {th }}$ model year).
3. Circuit operation reliability of the $T T$ system. The generally accepted concept of reliability - means the property of the object to keep all the parameters of the working process in time within the established limits, which ensures the performance of the required functions under the regulatory operating conditions. Failure is an event consisting in a complete or partial loss of the ability to perform specified functions. There are operating failures in which the required functions become practically impossible (for example, gear tooth failures in the $D A$ system) and parametric, in which the parameters of the object fall outside the permissible limits (for example, the $P W G$ vibration and noise level).

Basis for reliable assessment of function reliability of vehicles are always results of expensive production tests and the long-lived operation. As is well known because of the intense competition between manufacturing firms, much of this information, in particular regarding operational reliability, is a technical and commercial secret.

Function reliability of vehicles at the design stage is convenient to analyze as reliability of complex systems consisting of subsystems (electrical, mechanical, pneumatic and hydraulic) and their individual elements (TEM, frequency control unit, speed sensors, cardan's mechanisms, gear transmissions, bearings, etc.) [3-7]. Depending on the degree of complexity, each of these subsystems can also be considered as a system with its own elements. If reliability levels of the system's elements and also their communications among themselves are known, then methods of circuit and logical reliability are applied to prediction of reliability of systems. Such approach is justified for the electromechanical systems consisting of separate devices, units and modules. As failures of such elements are, as a rule, independent, results of their separate tests, statistical data on operational reliability and also calculated estimates can be used for prediction of reliability of systems [3, 4]. At the same time mechanical systems present in the form of the block diagram with sequentially and parallel connections of elements. Sequentially connected consider such elements, the failure of any of which leads to failure of all system. Parallel to connected consider an element which fails does not lead to failure of all system.

The TT can be represented as a recoverable sequentially or combined system (partially reservation) consisting of $n$ consecutive or series-parallel connected elements (parts, mobile and fixed connections, etc.) which failures it is customary to evaluate as independent at failures of operation and at parametrical failures. For passenger transport, the main types of parametrical failures are considered to be: reduction in energy efficiency, increased vibration and noise, breakages and damages of transmission elements. For a preliminary comparison of the circuits considered (table 2), the probabilities of failure-free operation of all the elements of the $T T$ system are assumed to be the same, for example $P_{j}=0,95(j=1, \ldots, l)$. In $T T$ with

two independent $D A$ it is assumed that constant reservation ensures that the trolleybus is operating at a reduced speed. If the " $a$ " part of the elements is not duplicated in the "TT system", and the other part " $b$ " is duplicated, the probability of fail-free operation is determined by such formulas: 


$$
P_{S T}=P_{a} \cdot P_{b} ; \quad P_{a}=\prod_{j=1}^{a} P_{j} ; \quad P_{b}=\prod_{j=1}^{b}\left(1-Q_{j}^{2}\right),
$$

where $Q_{j}$ - the probability of failure of the element $j$.

The results of the calculations allow us to roughly compare the known "TT systems", according to the system reliability indicator $P_{S T}$ (table 2$)$.
The highest value of system indicator of fail-safe operation $P_{S E}=0,931$ distinguish full electric transmission with a wheel formula $4 \times 4$ thanks to fewer sources of failure and structural reservation by the two $D A$ the $4^{\text {th }}$ generation (see table 2).

Table 2 - Circuit-logical models of the $T T$ system function's reliability

\begin{tabular}{|c|c|c|c|}
\hline $\begin{array}{l}\text { Wheel formula, } \\
\text { generation of } D A\end{array}$ & Block diagram of the "transmission system" & Calculation formulas & $P_{S T}$ \\
\hline $\begin{array}{l}4 \times 2, \\
D A \text { the } 1^{\text {st }} \\
\text { and the } 2^{\text {nd }} \text { generations }\end{array}$ & $-1-2-3-4 \frac{5}{6}-\frac{5}{6}$ & $\begin{array}{l}P_{S T}=P_{1} \cdot P_{2} \cdot P_{3} \cdot P_{4} \cdot P_{5}^{2} \\
P_{S T}=P_{1} \cdot P_{2} \cdot P_{3} \cdot P_{4} \cdot P_{6}^{2}\end{array}$ & 0,735 \\
\hline $\begin{array}{l}6 \times 4, \\
D A \text { the } 1^{\text {st }} \\
\text { and the } 2^{\text {nd }} \text { generations }\end{array}$ & \begin{tabular}{|c|c|c|}
4 & 6 & 6 \\
5 & 5 \\
4 & 5 & 5 \\
6 & 6 \\
\end{tabular} & $\begin{array}{l}P_{S T}=P_{7} \cdot\left[1-\left(1-P_{1} \cdot P_{2} \cdot P_{3} \cdot P_{4} \cdot P_{5}^{2}\right)^{2}\right. \\
P_{S T}=P_{7} \cdot\left[1-\left(1-P_{1} \cdot P_{2} \cdot P_{3} \cdot P_{4} \cdot P_{6}^{2}\right)^{2}\right.\end{array}$ & 0,883 \\
\hline $\begin{array}{l}4 \times 2, \\
D A \text { the } 3^{\text {rd }} \text { generation }\end{array}$ & \begin{tabular}{|c|c|c|c|} 
& 1 & 5 & 6 \\
& 6 & 1 \\
& 6 & 5 & 6 \\
\end{tabular} & $P_{S T}=P_{9} \cdot P_{1}^{2} \cdot P_{5}^{2} \cdot P_{6}^{2}$ & 0,70 \\
\hline $\begin{array}{l}6 \times 4, \\
D A \text { the } 3^{\text {rd }} \text { generation }\end{array}$ & 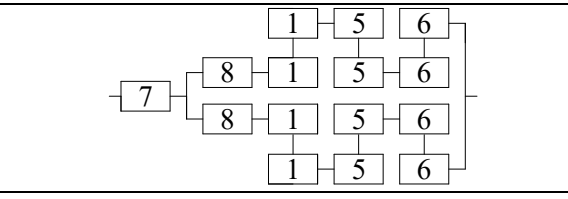 & $P_{S T}=P_{7} \cdot\left[1-\left(1-P_{8} \cdot P_{1}^{2} \cdot P_{5}^{2} \cdot P_{6}^{2}\right)^{2}\right]$ & 0,864 \\
\hline $\begin{array}{l}4 \times 2, \\
D A \text { the } 4^{\text {th }} \text { generation }\end{array}$ & $8-9$ & $P_{S T}=P_{8} \cdot P_{9}^{2}$ & 0,857 \\
\hline $\begin{array}{l}4 \times 4, \\
D A \text { the } 4^{\text {th }} \text { generation }\end{array}$ & -7 \begin{tabular}{c|c|c|}
9 & 9 \\
8 & 9 & 9 \\
& 9
\end{tabular} & $P_{S T}=P_{7} \cdot\left[1-\left(1-P_{8} \cdot P_{9}^{2}\right)^{2}\right]$ & 0,931 \\
\hline
\end{tabular}

Note. The following designations are accepted: 1 - TEM; 2 - cardan's mechanisms; 3 - main gear; 4 - mechanical differential; $5-P W G ; 6-I B G ; 7-B S ; 8$ - electric differential; $9-I M-W$.

A few smaller values (by $5 \ldots 8 \%$ ) correspond to electromechanical transmissions with the wheel formula $6 \times 4$ and two $D A$ the $1^{\text {th }}$ and the $3^{\text {rd }}$ generations with $P W G$.

Improving the circuit reliability of products by the method of redundancy is effectively used in practice in the design and operation of radio electronic products in which backup elements are small in size and easily switchable.

Specificity of complex electromechanical systems necessitates the analysis and accounting of functional relationships that determine the change in time of output parameters of the product, as well as the behavior of a complex system, taking into account the probabilistic relationships of its main elements [3].

Analysis of the circuit-logical models of "TT systems" function's reliability showed that when designing the TT of trolleybuses and electric buses the following solutions are used:

- Structured redundancy by introducing additional elements that ensure the preservation of the system's operability when one or several elements that are turned on in parallel are failed.
- Parametric redundancy ensuring the preservation of the operability of the system or its elements by facilitating operating modes, reducing operating loads and stresses by assigning surplus stocks by criteria of strength, rigidity, vibration resistance, durability, etc.

- Structural and parametric redundancy at the same time as reducing the number of failure sources.

4. Parametric reliability of the $P W G$. With regard to the problem of the TT reliability the parametric reliability of individual subsystems and their "weak links" (units, modules, parts and connections) is the main object of scientific research determining the operability of the system as a whole. At the same time, the parameters that characterize the qualitative characteristics of $T T$ should systematically reflect not only the functional purpose of the facility, but also the evolutionary changes in the requirements of consumers and manufacturers for the safety, environmental friendliness and comfort of passengers transporting.

For such systems most simply is the application of the principle of redundancy, which is that the resource of 
the product is set much lower than the average service life to failure. Presence of reserves of strength, rigidity, wear resistance, vibration resistance, heat resistance, etc. based on the main "criteria elements" of the system, established by the operation data, provides a margin of reliability, since the state domain of the product is removed from the limit values of the parameter. Redundancy allows continuously increasing the reliability of the system to the required level by increasing the efficiency of individual elements. For example, the reliability of gear pairs at factor of safety equal 2, fixed by both criterions - the tooth bending fatigue strength and pitting fatigue strength, which acceptable according to the manufacturing terms of General Motors, is $98 \%$. The reliability of bearings chosen fixed by criterion of pitting fatigue strength accordingly with $I S O$ recommendations is $90 \%$.

The principle of redundancy is a basic for methodology developed for vehicle's automotive transmission $[6,7]$. The gear pairs face width is calculated considering bending or surface wear only and considering both bending and surface fatigue. For the shafts the diameter minimum is calculated considering fatigue failure with maximum shear stress theory and to make the safe design of shaft system (i.e. with reliability greater than value $98 \%$ ) the factor of safety value should be greater than value 1,6 and similarly for bearings system the length of roller bearing is calculated considering contact stress between two cylinders and to design the bearing system safely the factor of safety should be greater than 1,4. As all these components are connected in series and to make the safe design of entire system the factor of safety should be kept more than value 2,5 for all gear pairs, shafts and bearings.

Despite the scientific validity, simplicity and attractiveness, in practice the application of the principle of redundancy in modern engineering sometimes leads to an unjustified overstatement of the dimensions and mass of the of the system's components (units, modules, mechanisms, links, elements). The main way for prediction of function and parametric reliability of mechanical system at projection - account probability distributions of an external loading and a carrying capacity of each element. The fundamental difference of projection of mechanical system from projection of electrical and electronic systems consists in what at projection of mechanical system the majority of elements (except for the reference and unified details, modules, units) projected and make targeted for this system. Such feature sharply changes possibilities of prediction of non-failure operation of mechanical (electromechanical) system causes need of the particular sequence of their projection.

The main feature of design of electromechanical TT structures for the given conditions of an arrangement and interface of all components in restricted space and also preferred application of the reference and unified details and modules, leads to the fact that many elements of system have the dimensions exceeding durability, necessary by criteria of strength, rigidity, stability of oscillations, i.e. are obviously reliable. At the same time in a design there are details and modules which dimensions cannot be increased owing to external restrictions. As a rule, such el- ements limit reliability of all system and in the reliability theory are known as "weak links" or "criteria elements".

Urban passenger electric transport refers to a group of machines operating up to the limit state in intermittent mode, while the period of use significantly exceeds the waiting period. In this case, failures of "weak links" associated with fatigue strength and metal wear are modeled using the universal Weibull distribution characterized by the following functions:

probability of failure-free operation

$$
P(t)=e^{-t^{m} / t_{0}}
$$

density of distribution

$$
f(t)=\frac{m}{t_{0}} t^{m-1} e^{-t^{m} / t_{0}}
$$

failure rate

$$
\lambda(t)=\frac{f(t)}{P(t)}=\frac{m}{t_{0}} t^{m-1},
$$

where $m>0$ - form parameter;

$$
t_{0}>0 \text { - scale parameter. }
$$

The possibilities and universality of Weibull distribution are as follows:

- with $m<1$ function $\lambda(t)$ and $f(t)$ operating time to failure, decreasing;

- with $m=1$ function $\lambda(t)=$ const, which corresponds to the exponential distribution;

- with $m=2$ function $\lambda(t)$ linear, which corresponds to Rayleigh distribution;

- with $m=3,3$ the distribution approaches to normal.

The task of increasing the level of reliability of typical components of vehicles is formalized at the stage of selecting the main indicators of reliability and rationing their values by the designer or directly by the customer. At the same time, some reliability indicators, as a rule, come into conflict with other quality indicators, as result the final decision is a compromise. The probability of fail-free operation $P(t)$ is first of all rated, indicating the resource $L$, during which this probability is realized. The $T T$ system is included in the class of products, the reliability of which is due to a complex of increased requirements for safety, ergonomics, comfort, regularity and economy of passenger transportation.

To assess the reliability of the transmission elements, a Gamma-percentage, medium (up to the first failure) and full resource (up to the limit state) is used, as well as the normalized value of the availability factor for basic components [3-6]. In this case, the uptime of several elements of the system may not correspond to the Weibull distribution, it is important that the failures of such elements do not dominate the others. Studies of the reliability of planetary gears as part of the helicopter's main transmission have shown that the resource Weibull distribution densities of the system as a whole in terms of parameters approaches the resource allocation function of the "weak 
link" [8]. The load capacity of the $P W G$ with internal gearing can be limited both by the fatigue strength of the teeth and by the performance of the planet bearings, depending on the values of the characteristic parameter $n \cdot N_{\Sigma}$ (where $n$ - rotation frequency, $N_{\Sigma}$ - equivalent number of loading cycles). In trolleybuses during electro dynamic braking the $T T$ operates in the driven mode from 20 to $40 \%$ of the time and, as a result, the teeth are loaded from different sides [9]. For the $T T$ within the $P W G$ a limitation in the outer diameter and, as a consequence, a thinwalled construction of the ring is characteristic. Structures of the $P W G$ with braked rings are used in the trolleybus's models of not imported and foreign production, containing $n_{p}=3 \ldots .5$ planets (table 3 ).

The increase in the number of planets reduces the vibration activity of the $P W G$ modules and the $D A$ subsystem as a whole, while the complexity of balancing load balancing between planets and the standard values of operational reliability and durability increases.

The probability of fail-free operation of $P W G$ can be determined in accordance with the formula (1) as a simple product of the probabilities of fail-free operation of system's main elements. When the probabilistic relationships between the system elements are correlated, the application of the formula (1) leads to a significant underestimation of the actual reliability of the system. For such cases the application of following dependence, the accuracy of which is confirmed by the practice of calculating highly reliable systems, is justified [3]:

$$
P_{P W G}=\left[\sum_{t=1}^{K} \frac{1}{P_{t}}-(K-1)\right]^{-1},
$$

where $P_{t}$ - probability of fail-free operation according to the $t$-criterion;

$K$ - number of criterions.

Statistical information on faults and failures of products received from operating enterprises, as a rule, does not have the necessary volume for use in forecasting reliability indicators. More complete information on the state of the TT system and the laws of the distribution of the life of individual elements can be obtained from repair companies. In this case, the repair and maintenance periods set by the manufacturer have a significant impact on the reliability. As a rule, the accumulation of a sufficient amount of information occurs during a period when the vehicle, individual units, mechanisms and modules are morally obsolete and no longer produced. Fundamental information on the function of the state of electromechanical systems in time, represented in the form of analytical, empirical or imitation models of failures, is obtained on the basis of physical-mechanical studies [10-14]. The combination of modern methods of analyzing the statistical data of repair enterprises and physical and mechanical methods of research makes it possible to significantly increase the objectivity and reliability of the results of forecasting the TT average resource.
Table 3 - Examples of technical characteristics of $D A$ within the $P W G$ 's typical structure

\begin{tabular}{|l|c|c|c|}
\hline \multicolumn{1}{|c|}{ Characteristics } & \multicolumn{2}{|c|}{$\begin{array}{c}\text { Models of } D A \\
\text { with } P W G \\
\text { produced by firm } \\
R A B A, \text { Hungary: }\end{array}$} & $\begin{array}{c}\text { Model of } D A \\
\text { with } \\
A M-W \\
\text { produced by } \\
\text { firm } Z F, \\
\text { Germany }\end{array}$ \\
\cline { 2 - 4 } & 118.77 & 318.78 & $A V E-130$ \\
\hline Average resource, km & 600000 & 600000 & 700000 \\
\hline Warranty mileage, km & 240000 & 280000 & 320000 \\
\hline Standard noise level, dB & 84 & 82 & 72 \\
\hline$D A$ weight, kg & 645 & 650 & $2 \times 500$ \\
\hline $\begin{array}{l}\text { Maximum power of } T E M, \\
\text { kW }\end{array}$ & 280 & 280 & $2 \times 125$ \\
\hline $\begin{array}{l}\text { Maximum torque at the } \\
\text { inlet, Nm }\end{array}$ & 4270 & 4270 & 11000 \\
\hline $\begin{array}{l}\text { Transmission ratio of } \\
\text { the } D A \text { gears }\end{array}$ & 10,699 & 10,673 & 22,66 \\
\hline $\begin{array}{l}\text { Transmission ratio of } \\
\text { the } P W G\end{array}$ & 3,461 & 3,33 & 5,818 \\
\hline $\begin{array}{l}\text { Type of the } P W G \\
\text { transmission, } \\
\text { number of planets }\end{array}$ & $\begin{array}{l}\text { straight- } \\
\text { toothed, } \\
3 \text { planets }\end{array}$ & $\begin{array}{l}\text { straight- } \\
\text { toothed, } \\
5 \text { planets }\end{array}$ & $\begin{array}{c}\text { helical, } \\
4 \text { planets }\end{array}$ \\
\hline
\end{tabular}

According to the statistics of the failures of planetary gear boxes in the turbocharged aggregates the failure of rings with internal teeth is more than $20 \%$ [3]. Similar statistics are typical for the $P W G$ in trolleybus's transmission $[8,10,11]$. So for the period of 12 months, the maintenance and repair service of trolleybus in depot "Odessa urban electric trans" recorded $62 P W G$ failures $[10,11]$. Observation was conducted over 90 samples, of which the standard sizes $R A B A 118 / 70$ - 26 units, $R A B A$ 118/71 - 12 units, RABA 118/72 - 28 units, RABA 118/73 - 20 units, $R A B A 118 / 77-4$ units. Ring (module 3,25 $\mathrm{mm}$, number of teeth $z_{R}=64$ ) made of forgings $35 \mathrm{CrNi}$ steel, the hardness of the working surfaces of the teeth after improvement is $269 \ldots 302 \mathrm{HB}$; the sun gear $\left(z_{s}=26\right)$ is made of forgings steel $40 \mathrm{CrNiMoN}$, after hardening and nitrating by a thickness of $0,1 \ldots 0,9 \mathrm{~mm}$, the hardness of the working surfaces of the teeth is $50 . .56 \mathrm{HRC}$, the core $-269 . . .302 \mathrm{HB}$; planets $\left(z_{p}=19\right)$ are made of forgings steel 20CrNiMo, after improvement, cementation and hardening the hardness on the surface of the teeth is 56...63 HRC, the core $-300 . .400 \mathrm{HB}$.

The compactness of the coaxial $P W G$ design excludes a superficial monitoring of the technical condition of most parts and joints during operation, hence the sudden failure of the transmission through the breakage of the teeth $(B T)$ and the rim $(B R)$ of the ring, disk of the planets and carrier. After the dismantling and during the repair, other damages were also detected, namely: plastic deformations $(P D)$ of the teeth of the planets, and the ring suspension clutch; abrasive wear $(A W)$ of sun gear, planets, planet axes, ring, toothed ring suspension gear clutch; fatigue cracks $(F C)$ of teeth, ring rim, planet disc, carrier; fatigue micro-cracks $(M C)$ of the working surfaces of the teeth and of the raceways of the bearings of the planets (fig. 4, table 4). 


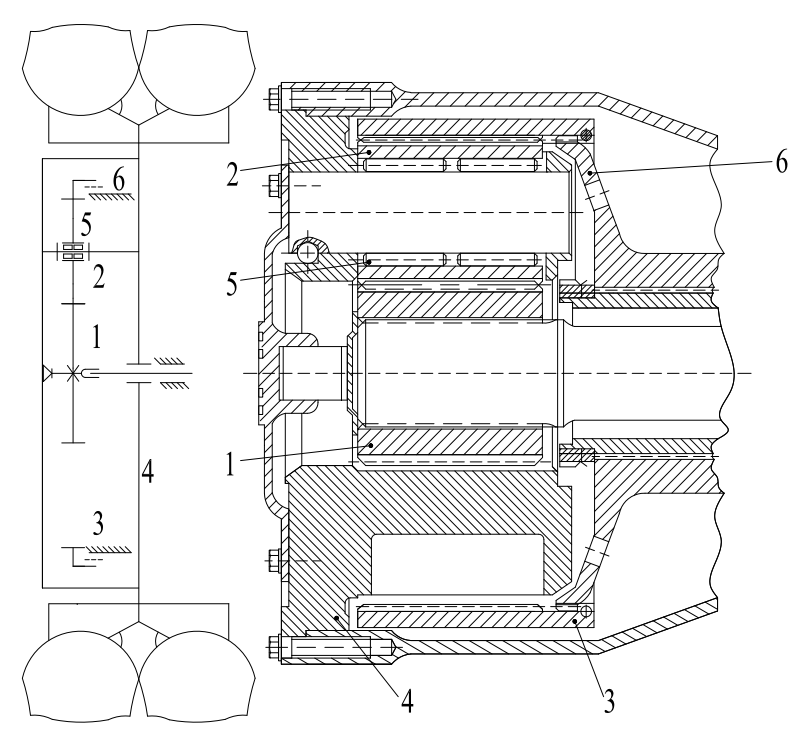

Fig. 4 - Transmission scheme of $D A$ the $1^{\text {st }}$ generation:

1 - sun gear; 2 - planet; 3 - ring; 4 - carrier;

5 - planet bearings; 6 - gear suspension clutch

Table 4 - Failure statistics of $P W G$ based on observation data of maintenance and repair service of the trolleybus depot

\begin{tabular}{|l|c|c|c|c|c|}
\hline \multicolumn{1}{|c|}{$\begin{array}{l}\text { Weak links: } \\
\text { criteria elements }\end{array}$} & \multicolumn{5}{c|}{ Criteria } \\
\cline { 2 - 6 } $\begin{array}{l}\text { Sun gear: } \\
\text { teeth }\end{array}$ & - & - & 2 & - & 2 \\
\hline $\begin{array}{l}\text { Planets: } \\
\text { teeth } \\
\text { disk } \\
\text { axes }\end{array}$ & 8 & - & 7 & - & 4 \\
\hline $\begin{array}{l}\text { Ring: } \\
\text { teeth } \\
\text { rim }\end{array}$ & - & - & - & 3 & - \\
\hline $\begin{array}{l}\text { Planet carrier: } \\
\text { the jumpers between } \\
\text { axes of bearings }\end{array}$ & - & 2 & 2 & 8 & - \\
\hline $\begin{array}{l}\text { Satellite bearings: } \\
\text { raceways }\end{array}$ & - & - & - & 2 & - \\
\hline $\begin{array}{l}\text { Ring suspension } \\
\text { clutch: } \\
\text { teeth }\end{array}$ & - & - & - & - & 1 \\
\hline $\begin{array}{l}\text { Total failures: 62, } \\
\text { among of their with fa- } \\
\text { tigue nature - 53 \% }\end{array}$ & 13 & 2 & 14 & 25 & 8 \\
\hline
\end{tabular}

The calculated averaged value of the dimensionless indicator $\lambda_{t} t \equiv t / \bar{t}$ for the exponential distribution at $\lambda(t)=$ const corresponds to the time between failures of $\bar{t}=280$ hours, with the failure rate being $\lambda_{t}=(2,0 \ldots 2,4) \cdot 10^{-4} \mathrm{~h}^{-1}$. Appropriate probability of failfree operation is $P_{P W G}=0,78[10,11]$.

When the planets rotate, cyclic normal stresses predominate in the rim of the stopped ring (radial $-\sigma_{r}$, from bending teeth and circumference $-\sigma_{t}$, from bending and stretching the rim). If the thickness of the rim $\delta$ is much higher than the height of the teeth $h$, the stresses $\sigma_{t}$ not great, but cyclic flexural stresses $\sigma_{r}$ can lead to the nucleation of fatigue micro-cracks in the fillets. With comparable values of $\delta$ and $h$, as a result of the joint action of the stresses $\sigma_{r}$ and $\sigma_{t}$, the fatigue crack accelerates rapidly in the radial direction, which leads to the destruction of the gear ring [15-17].

Based on the results of full-scale tests with tensometry of torque on the axis of the trolleybus $M A Z-103 T$, a family of probabilistic fatigue curves for internal gear teeth was formed in accordance with the linear model of stacking of fatigue damages by Palmgren-Miner and the statistical theory of the similarity of fatigue failure of Serensen-Kogayev, ring for the example of $P W G R A B A$ 118 by the criterion of fatigue resistance of a thin-walled rim (table 5) [17].

Table 5 - Forecasting results of Gamma-percentage resource $L_{\gamma}$ of gear ring

\begin{tabular}{|c|c|c|c|c|}
\hline $\begin{array}{c}\text { Index, } \\
\text { dimension }\end{array}$ & \multicolumn{4}{|c|}{ Value } \\
\hline$\gamma, \%$ & 50 & 80 & 90 & 95 \\
\hline $\log L_{\gamma}$ & - & 6,20 & 6,14 & 6,07 \\
\hline$L_{\gamma}$, cycles & $\infty$ & $1,58 \cdot 10^{6}$ & $1,38 \cdot 10^{6}$ & $1,17 \cdot 10^{6}$ \\
\hline
\end{tabular}

It has been established that the average probabilistic limit of endurance of the ring $\sigma_{-1 E}^{(50)}=84,5 \mathrm{MPa}$ exceeds the values of equivalent stresses, respectively, at starting $\sigma_{-l e}=81,33 \mathrm{MPa}$ and at $E D$-braking of the trolleybus $\sigma_{-l e}=79 \mathrm{MPa}$, but with higher values of the probability of non-destruction $\gamma \geq 80 \%$, the life of the epicycle rim turns out to be limited at the level of $2 \cdot 10^{6}$ cycles of teeth loading. The warranty resource for planetary $P W G$ the type $R A B A 118$ is set at 240 thousands km (approximately $10^{9}$ cycles of the load of the ring teeth), which corresponds to the calculated probability of non-destruction and is consistent with the statistically significant value $P_{P W G}=78 \%$.

The increased deviations from the coaxial alignment of the coupled teeth in the "planet-ring" gearing, due to the wear of the gear clutches of the "floating suspension" of the ring, lead to an expansion of the region of unstable parametric oscillations, an increase in the level of vibrations and, as a result, the destruction of "weak link" - the ring. The resonance phenomena of parametric oscillations are high-frequency and, as a rule, correspond to the $3^{\text {rd }} \ldots 4^{\text {th }}$ eigen frequencies of the $T T$ system [18]. To analyze the stability of parametric oscillations of the $P W G$ ring is suggested a criterion in such form [19]:

$$
k_{p}=\sum_{i=1}^{n}\left(1-\frac{S_{i}}{S_{B, i}}\right),
$$

where $S_{i}$ and $S_{B, i}$ - are the areas of the instability zone and the base zone for $i$-th parametric resonance in the Ains-Strett diagram.

Based on the design of the $P W G$ type $R A B A 118$ the calculated values of the probability index for the stability of the parametric oscillations of the ring $P_{R}=k_{R} \cdot 100 \%$, which directly affect the manifestation of resonant phenomena, contribute to the accelerated development of fatigue cracks during the movement of the trolleybus (table 6). In accordance with equation (6), a complex cal- 
culation estimate of the probability $P_{L R}$ of fail-free operation of the $P W G$ has been obtained, based on two related criteria $L_{\gamma}, P_{R}$ - the fatigue strength and stability of parametric oscillations of a "criteria element" - thin-walled ring (table 7).

Table 6 - Probability of stability $P_{R}, \%$, parametric oscillations of the ring

\begin{tabular}{|c|c|c|c|}
\hline Type of engagement & \multicolumn{2}{|c|}{ straight-toothed } & helical \\
\hline $\begin{array}{c}\text { Impact kinematic } \\
\text { inaccuracies }\end{array}$ & + & 67 & \multirow{2}{*}{98} \\
\cline { 2 - 3 } & - & 83 & \\
\hline
\end{tabular}

Table 7 - Double-criteria evaluation probability of fail-free operation of the $P W G$

\begin{tabular}{|c|c|c|c|}
\hline Indicators, \% & \multicolumn{3}{|c|}{ Value } \\
\hline$\gamma$ & \multicolumn{3}{|c|}{78} \\
\hline$P_{R}$ & 67 & 83 & 98 \\
\hline$P_{L R}$ & 56 & 67 & 77 \\
\hline
\end{tabular}

Comparison of double-criteria estimates of the probability of fail-free operation of the "criteria element" - the $P W G$ ring, with statistical estimates based on the data of the operating and repair enterprise confirms the sufficient adequacy of the developed multi criteria accuracy methodology, and also allows one to substantiate the most effective directions of ensuring the standard level of reliability of analogous components in the $T T$ design or modernization.

For example:

- to ensure the normative parametric reliability of the $P W G$ on the criterion of fatigue strength of the ring it is recommended to maximally increase the endurance limit of the rim due to the optimal geometry of the fillet teeth, as well as the use of superficially hardening technologies;

- to reduce the probability of manifestation of parametric resonances in the $P W G$ system, the engagement and "floating suspension" elements must be manufactured with greater kinematic accuracy (by $1 . . .2$ degrees) compared with similar elements of in-line gears;

- the use of helical gearing with a total overlap factor $\varepsilon_{\gamma}>3,0$ simultaneously provides the redundancy of the load capability of the $P W G$ and increases the probability of its failure-free operation by the vibration resistance criterion;

- to improve the operation reliability of the $T T$ systems "on the state" and to predict the residual life, it is necessary to ensure the controllability of the design, i.e. the ability to monitor the technical state of "weak links" and "criteria elements" using the most effective for today vibration diagnostics.

5. Conclusions and future research. Stages of technical evolution of traction transmission of passenger electric transport are established. The technique of taking note of parameters of TT system operation reliability at assessment of technical level of trolleybus's produced models is developed. Objective functional effectiveness of the known designs of $P W G$ and existence of reserves for further perfecting of designs of electromechanical transmission on system indexes of reliability, taking into account statistics of service data and scientific research, is confirmed. Most efficient way of parametrical redundancy of "weak links" and "criteria elements" of the TT system, based on $D A$ the $1^{\text {th }}$ and $3^{\text {rd }}$ generations, is protection of $P W G$ from harmful effects - shock loads, vibrations, the resonance phenomena.

The conclusions are based on the published own results and of other researchers, as well as the experience of practice of operation, designing and manufacturing.

Important conditions for advanced compliance of the designed of $D A$ with the level of analogues produced by the world's leading firms are:

- investigation and optimization while design of the parametric reliability of "weak links" and "criteria elements" of the $T T$ by the criteria of fatigue strength and vibration resistance in accordance with the requirements of customers and manufacturers;

- the monitoring of the technical state and research on the parametric reliability of "weak links" and "criteria elements" in the composition of recoverable $T T$ systems and subsystems of trolleybuses with a long guarantee life.

\section{References}

1. Гутиря С.С., Борденюк Д.М., Чанчін А.М. Технічна еволюція світового і вітчизняного тролейбусобудування. Праці Одеського політехнічного університету: Науковий та науково-виробничий збірник. Одеса: ОНПУ. 2011, Вип. 1 (35). С. 42-48.

2. Сафонов А.И. Особенности режимов нагружения и направления развития тяговых трансмиссий троллейбусов. Автомобильная промышленность. 2015. № 4. С. 8-15.

3. Проников А.С. Параметрическая надежность машин. М.: Издво МГТУ им. Н.Э. Баумана, 2002. 560 с.

4. Zhang Y., Liu Q. Reliability-based Design of automobile components. Proc. Instn. Mech. Engrs. Automobile Engineering. 2002. Vol. 216. Part D: J. Pp. 455-471.

5. Wen B., Zhang Y.M. Practical Reliability Based Design of Gear Pairs. Journal of Mechanism and Machine Theory. 2003, no. 38. Pp. 1363-1370.

6. Zhang Y.M. Reliability-based Design for Automobiles in China Front. Mech. Eng. China. 2008. No. 3(4). Pp. 369-376.

7. Khan D.I., Virtanen S., Verma A.K. Automotive transmission system design based on reliability parameters. Journal of Reliability and Statistical Studies. Issue 2. 2012, Vol. 5. Pp. 59-76.

8. Miloslav Kepka, Kepka Jr. Miloslav. Parametric calculations of fatigue life of critical part of trolleybus rear axle. "7th International Conference on Fatigue Design, Fatigue Design 2017". 29-30 November, 2017. Senlis, France, Procedia Engineering. Pp. 227-238.

9. Руктешель О.С., Минюкович С.М., Захарик А.А. Исследование нагруженности трансмиссии троллейбуса. Вестник БНТУ. Минск. 2006, №6. С. 48-51.

10. Гутиря С.С., Борденюк Д.М. Надійність експлуатації планетарних колісних редукторів. Вісн. агр. науки Причорномор'я. Миколаїв: МДАУ. 2007, Вип. 2(41). С. 130-134.

11. Gutyrya S., Bordeniuk D. Diagnostics of damages in trolleybus wheel reduction gears. Motrol, Tom 10a. Lublin, 2008. P. 65-71.

12. Gutyrya S.S., Zablonsky K.I., Yaglinsky V.P. System Modeling of Gears Design Quality. International Conference on Gears. VDI, Munich, Germany. 2005. Pp. 417-434.

13. Оборский Г.А., Дащенко А.Ф., Дмитришин Д.В., Усов А.В. Моделирование систем: монография. Одесса: Астропринт, 2013. 664 с.

14. Оборський Г.О., Гутиря С.С., Яглінський В.П. Надійність роботів-верстатів і промислових платформ на основі механізмів паралельної структури. Методи розв'язання прикладних задач механіки деформівного твердого. Дніпропетровськ: Ліра. 2011, Вип. 12. С. 246-254.

15. Ariza De Miguel J., Gutyrya S.S., Jomyak Y.M. Tensiones en ejes huecos con una grieta superficial bajo flexión rotativa. Revista DYNA, 2014. Vol. 89, no. 1. Pp. 85-88.

16. Zheglova V., Khomiak Yu., Medvedev S., Nikolenko I. Numerical and analytical evaluation of service life of the details axial piston 
hydraulic machines with complicated configuration under cyclic loading. Procedia Engineering. Elsevier. 2017, Vol. 176. P. 557-566.

17. Гутыря С.С., Медведев С.А., Хомяк Ю.М., Чанчин А.Н. Вероятностный анализ усталостной прочности эпицикла колесного редуктора троллейбуса. Вісник НТУ "ХПI". Харків, НТУ "ХПІ", 2017. №25 (1247). C. 37-43.

18. Gutyrya S., Yaglinskyi V., Chanchin A. Parametrical Fluctuations of Epicycle in Wheel Gearboxes. British Journal of Applied Science \& Technology. 2016, 13(2). Pp. 1-8.

19. Яглинский В.П., Гутыря С.С., Чанчин А.Н., Хомяк Ю.М. Параметрические колебания в планетарных колесных редукторах. Вісник НТУ "ХПІ". Харків, НТУ "ХПІ". 2018. № 25 (1301). С. 156-162.

\section{References (transliterated)}

1. Hutyria S.S., Bordeniuk D.M., Chanchin A.M. Tekhnichna evoliutsiia svitovoho i vitchyznianoho troleibusobuduvannia. [Technical evolution of the world and domestic trolleybus structure]. Pratsi Odeskoho politekhnichnoho universytetu: Naukovyi ta naukovovyrobnychyi zbirnyk. Odesa, ONPU. 2011, Vol. 1 (35). Pp. 42-48.

2. Safonov A.I. Osobennosti rezhimov nagruzheniya i napravleniya razvitiya tyagovykh transmissiy trolleybusov [Features of loading regimes and the direction of development of traction transmissions of trolleybuses]. Avtomobilnaya promyshlennost. 2015. No. 4. Pp. 8-15.

3. Pronikov A.S. Parametricheskaya nadezhnost mashin [Parametric reliability of machines]. Moscow, Izd-vo MGTU im. N.E. Baumana 2002. $560 \mathrm{p}$.

4. Zhang Y., Liu Q. Reliability-based Design of automobile components. Proc. Instn. Mech. Engrs. Automobile Engineering. 2002. Vol. 216. Part D: J. Pp. 455-471.

5. Wen B., Zhang Y.M. Practical Reliability Based Design of Gear Pairs. Journal of Mechanism and Machine Theory. 2003, no. 38 Pp. 1363-1370.

6. Zhang Y.M. Reliability-based Design for Automobiles in China Front. Mech. Eng. China. 2008. No. 3(4). Pp. 369-376.

7. Khan D.I., Virtanen S., Verma A.K. Automotive transmission system design based on reliability parameters. Journal of Reliability and Statistical Studies. Issue 2. 2012, Vol. 5. Pp. 59-76.

8. Miloslav Kepka, Kepka Jr. Miloslav. Parametric calculations of fatigue life of critical part of trolleybus rear axle. "7th International Conference on Fatigue Design, Fatigue Design 2017". 29-30 November, 2017. Senlis, France, Procedia Engineering. Pp. 227-238.

9. Rukteshel O.S., Minyukovich S.M., Zakharik A.A. Issledovaniye nagruzhennosti transmissii trolleybusa [Investigation of the loading of the trolleybus transmission]. Vestnik BNTU. Minsk. 2006. No. 6. Pp. 48-51.

10. Hutyria S.S., Bordeniuk D.M. Nadiinist ekspluatatsii planetarnykh kolisnykh reduktoriv [Reliability of operation of planetary wheel gearboxes]. Visn. ahr. nauky Prychornomor ia. Mykolaiv, MDAU Publ., 2007, Vol. 2(41). Pp. 130-134.

11. Gutyrya S., Bordeniuk D. Diagnostics of damages in trolleybus wheel reduction gears. Motrol, Tom 10a. Lublin, 2008. Pp. 65-71.

12. Gutyrya S.S., Zablonsky K.I., Yaglinsky V.P. System Modeling of Gears Design Quality. International Conference on Gears. VDI, Munich, Germany. 2005. Pp. 417-434.

13. Oborskiy G.A., Dashchenko A.F., Dmitrishin D.V., Usov A.V. Modelirovaniye sistem: monografiya [Modeling of systems: monograph]. Odessa, Astroprint Publ., 2013. 664 p.

14. Oborskyi H.O., Hutyria S.S., Yahlinskyi V.P. Nadiinist robotivverstativ i promyslovykh platform na osnovi mekhanizmiv paralelnoi struktury [Reliability of robots-machine tools and industrial platforms on the basis of mechanisms of parallel structure]. Metody rozviazannia prykladnykh zadach mekhaniky deformivnoho tverdoho. Dnipropetrovsk, Lira Publ., 2011, Vol. 12. Pp. 246-254.

15. Ariza De Miguel J., Gutyrya S.S., Jomyak Y.M. Tensiones en ejes huecos con una grieta superficial bajo flexión rotativa. Revista DYNA, 2014. Vol. 89, no. 1. Pp. 85-88.

16. Zheglova V., Khomiak Yu., Medvedev S., Nikolenko I. Numerical and analytical evaluation of service life of the details axial piston hydraulic machines with complicated configuration under cyclic loading. Procedia Engineering. Elsevier. 2017, Vol. 176. Pp. 557-566.

17. Gutyrya S.S., Medvedev S.A., Khomyak Yu.M., Chanchin A.N. Veroyatnostnyy analiz ustalostnoy prochnosti epitsikla kolesnogo reduktora trolleybusa [Probability analysis of the fatigue strength of the epicyclic wheel gear reducer of a trolleybus]. Visnik NTU "KhPI" [Bulletin of the National Technical University "KhPI"]. Kharkiv, NTU "KhPI" Publ., 2017. No. 25 (1247). Pp. 37-43.

18. Gutyrya S., Yaglinskyi V., Chanchin A. Parametrical Fluctuations of Epicycle in Wheel Gearboxes. British Journal of Applied Science \& Technology. 2016, 13(2). Pp. 1-8.

19. Yaglinskiy V.P., Gutyrya S.S., Chanchin A.N., Khomyak Yu.M. Parametricheskiye kolebaniya $\mathrm{v}$ planetarnykh kolesnykh reduktorakh [Parametric oscillations in planetary wheel gearboxes]. Visnik NTU "KhPI" [Bulletin of the National Technical University "KhPI"]. Kharkiv, NTU "KhPI" Publ., 2018. No. 25 (1301). Pp. 156-162.

Received 19.06.2018

\section{Відомості про авторів / Сведения об авторах / About the Authors}

Оборський Генадій Олександрович (Оборский Геннадий Александрович, Oborskyj Genadij Oleksandrovych) - доктор технічних наук (Dr. habil. of Eng. S.), професор, Одеський національний політехнічний університет, ректор; м. Одеса, Україна; ORCID: https://orcid.org/0000-0002-5682-4768; e-mail: rector@opu.ua

Гутиря Сергій Семенович (Гутыря Сергей Семенович, Hutyria Serhij Semenovych) - доктор технічних наук (Dr. habil. of Eng. S.), професор, Одеський національний політехнічний університет, директор Українсько-іспанського навчально-наукового інституту; м. Одеса, Україна; ORCID: https://orcid.org/0000-0003-1257-3933; e-mail: hutyria@opu.ua Яглінський Віктор Петрович (Яглинский Виктор Петрович, Yaglinskij Victor Petrovych) - доктор технічних наук (Dr. habil. of Eng. S.), професор, Одеський національний політехнічний університет, професор кафедри підйомнотранспортного та робототехнічного обладнання; м. Одеса, Україна; ORCID: https://orcid.org/0000-0001-9466-6927; e-mail: viknatvov@gmail.com

Чанчін Андрій Миколайович (Чанчин Андрей Николаевич, Chanchin Andrij Mykolajovych) - Одеський національний політехнічний університет, асистент кафедри машинознавства і деталей машин; м. Одеса, Україна; ORCID: https://orcid.org/0000-0002-1483-8635; e-mail: chanchin@opu.ua 